\title{
Kelayakan Air Danau Toba di Wilayah Kabupaten Tapanuli Utara Untuk Air Baku dan Rekreasi Air
}

\section{The Suitability of Lake Toba's water in North Tapanuli Regency for Raw water and Recreational Water}

\author{
JOKO PRAYITNO SUSANTO*, AGUNG RIYADI, DAN YUDHI SOETRISNO GARNO
}

Pusat Teknologi Lingkungan, Badan Pengkajian dan Penerapan Teknologi

Email: joko.susanto@bppt.go.id

\begin{abstract}
In the area of North Tapanuli Regency, a special economic zone for Taman Bunga Tourism will be developed. In the future, this area will require a large amount of clean water for consumption and water tourism facilities. To anticipate this water demand, a study was carried out to determine the feasibility of Lake Toba water in the North Tapanuli Regency area for drinking water, raw water, and water tourism infrastructure. This study uses in-situ observation and sampling methods for laboratory analysis according to ISO 5667-6:2014 and ISO 5667-3:2012 procedures. This study implies that Lake Toba water in the North Tapanuli Regency is not yet feasible to be used as raw water for drinking water and water recreation. It still has several parameters: $B O D, C O D$, total phosphate, iron, and barium that do not meet the quality standard values. So that to take advantage of it, it is necessary to reduce the concentration of these parameters.
\end{abstract}

Keywords: Lake Toba, North Tapanuli, raw water, water recreation, water quality standard.

\begin{abstract}
ABSTRAK
Di wilayah Kabupaten Tapanuli utara akan dikembangkan kawasan ekonomi khusus Pariwisata Taman Bunga, sehingga pada saatnya nanti kawasan ini akan memerlukan air bersih dalam jumlah besar untuk konsumsi dan sarana wisata air. Dalam rangka mengantisipasi kebutuhan air tersebut maka dilaksanakan penelitian untuk mengetahui kelayakan air Danau Toba di wilayah Kabupaten Tapanuli Utara untuk air baku air minum dan sarana prasarana wisata air. Penelitian dlaksanakan dengan pengamatan in-situ dan pengambilan sampel untuk analisis laboratorium sesuai prosedur ISO 5667-6:2014 dan ISO 5667-3:2012. Penelitian ini mengisaratkan bahwa air Danau Toba di wilayah Kabupaten Tapanuli Utara tidak layak untuk dijadikan air baku air minum dan sarana prasarana rekreasi air karena masih memiliki parameter BOD, COD, total fosfat, besi, dan barium yang tidak memenuhi nilai baku mutu yang berlaku. Untuk memanfatkan air Danau Toba di wilayah Kabupaten Tapanuli Utara diperlukan upaya penurunan konsentrasi parameter-parameter tersebut.
\end{abstract}

Kata kunci: Danau Toba, Tapanuli Utara, bahan baku air, wisata air, baku mutu.

\section{PENDAHULUAN}

\subsection{Latar Belakang}

Danau Toba merupakan danau terbesar di Indonesia yang terletak di Provinsi Sumatera Utara. Danau ini terletak pada ketinggian $995 \mathrm{~m}$ di atas permukaan laut memiliki luas permukaan $1.124 \mathrm{~km}^{2}$ dengan kedalaman $508 \mathrm{~m}^{(1,2)}$. Di area perairannya terdapat lima pulau yang masuk dalam wilayah administrasi kabupaten yang berbeda-beda, yaitu Pulau Tao (Kabupaten Samosir), Pulau Tolping (Kabupaten Dairi), Pulau Tulas (Kabupaten Samosir), Pulau Sibandang (Kabupaten Taput), dan Pulau Samosir (Kabupaten Samosir).

Sebagai danau terluas dengan massa air yang sangat besar, Danau Toba memiliki peran yang sangat penting untuk mendukung berbagai kegiatan perekonomian di Provinsi Sumatera Utara. Kegiatan-kegiatan tersebut antara lain pemanfatan air Danau Toba untuk pembangkit tenaga listrik, sebagai bahan baku air bersih oleh PDAM, dimanfaatkan oleh penduduk sebagai tempat budidaya ikan menggunakan keramba jaring apung (KJA), perikanan, pariwisata air dan transportasi.

Pada Tahun 2011 melalui Peraturan Pemerintah (PP) Nomor 50 Tahun 2011 tentang Rencana Induk Kepariwisataan Nasional Tahun 2010-2025(3), Danau Toba telah ditetapkan sebagai salah satu kawasan strategis pariwisata nasional (KSPN) ${ }^{(3)}$. Dengan demikian fungsi utama kawasan Toba dan sekitarnya adalah sebagai kawasan pengembangan pariwisata. Untuk mendukung percepatan pengembangan kepariwisata, khususnya percepatan 
pembangunan infrastruktur transportasi, listrik, dan air bersih di kawasan Danau Toba, Pemerintah membentuk Badan Otorita Pengelola Kawasan Pariwisata Danau Toba melalui Peraturan Presiden Nomor 49 Tahun 2016 dengan tugas melaksanakan pembangunan dan pengelolaan di kawasan pariwisata Sibisa dan kawasan pariwisata taman bunga.

Rencana pengembangan kawasan Danau Toba dan sekitarnya sebagai destinasi wisata diharapkan akan mampu mendatangkan wisatawan, bukan dari dalam negeri saja tetapi juga dari mancanegara. Untuk menyambut kedatangan wisatawan yang diundang ke kawasan wisata Danau Toba sudah tentu harus dipersiapkan keperluan mereka selama tinggal di kawasan. Keperluan mereka selama di kawasan adalah air bersih untuk minum dan massa air untuk rekreasi. Kedua kebutuhan air untuk wisatawan tersebut sebenarnya dapat dipenuhi dengan air Danau Toba, asalkan air Danau Toba memenuhi baku mutu air danau yang berlaku seperti tertera pada PP Nomor 22 Tahun 2021 tentang Penyelenggaraan Perlindungan dan Pengelolaan Lingkungan Hidup ${ }^{(4)}$

Sesuai PP Nomor 22 Tahun 2021 tentang Penyelenggaraan Perlindungan dan Pengelolaan Lingkungan Hidup, terdapat dua kelompok baku mutu air, yaitu (1) kelompok baku mutu air sungai dan sejenisnya, dan (2) kelompok baku mutu air danau dan sejenisnya. Masing masing kelompok tersebut dibagi dalam empat kelas sesuai peruntukannya, yaitu Kelas satu, Kelas dua, Kelas tiga dan Kelas empat.

Masing-masing kelas air tersebut disusun berdasarkan perbedaan besaran nilai parameter untuk jumlah parameter yang sama. Semakin besar nilai besaran parameter akan semakin tinggi kelas airnya, sehingga semakin tinggi kelas air semakin mudah dipenuhi.

Sebagai kawasan pariwisata, air Danau Toba diharapkan dapat dimanfaatkan sebagai sumber air air baku air minum yang memenuhi persyaratan baku mutu air Kelas satu. Selain sebagai sumber air air baku air minum juga diharapkan memenuhi persyaratan untuk untuk sarana dan prasarana rekreasi air yang memenuhi persyaratan baku mutu Kelas dua.

Sejak terbentuk, Danau Toba mendapatkan suplai air dari daratan sekelilingnya, baik melalui sungai besar maupun kecil yang membawa limbah dari berbagai kegiatan domestik, perkotaan, pertanian, perkebunan, peternakan dan industri. Pencemaran air Danau Toba ini diperparah seiring dengan semakin berkembangnya usaha budidaya ikan yang menggunakan $\mathrm{KJA}^{(5,6,7)}$.

Indikasi terjadinya pencemaran air Danau Toba ini dapat diketahui dari adanya perubahan beberapa parameter kualitas air. Beberapa penelitian menunjukkan bahwa telah terjadi perubahan transparansi air (secchi depth) Danau Toba berkisar antara 7,5-11,5 meter (pada Tahun 1930 berubah menjadi sekitar 6,0-10,0 meter yang mengindikasikan bahwa air Danau Toba telah mengalami peningkatan kekeruhan ${ }^{(8,9)}$. Dalam penelitian yang sama, oksigen terlarut (DO) air Danau Toba di kedalaman $\geq 150$ meter yang semula antara 5,35-5,4 mg/l saat ini pada kedalaman yang sama berubah menjadi sekitar $0,5 \mathrm{mg} / \mathrm{/}^{(8)}$.

Penurunan transparansi air dan kandungan oksigen terlarut tersebut diduga disebabkan oleh terjadinya peningkatan kandungan bahan organik terlarut dalam badan air yang masuk daratan maupun langsung ke badan air tersebut ${ }^{(10)}$. Peningkatan bahan organik ke dalam badan air akan menyebabkan air menjadi keruh. Bahan organik ini di dalam air akan terdekomposisi dimana pada proses dekomposisinya membutuhkan oksigen yang terlarut dalam air, sehingga mengakibatkan terjadinya perubahan (penurunan) kandungan oksigen terlarut (DO) di perairan.

Indikasi terjadinya pencemaran air Danau Toba juga dapat diketahui dari adanya perubahan tingkat kesuburan air danau yang telah berubah dari yang semula status trofik perairannya adalah oligotrofik menjadi mesotrofik. Pencemaran ini juga ditunjukkan oleh perubahan kandungan $\mathrm{PO}_{4}$-fosfor dari 0,005 mg/l (1929) naik menjadi 0,05 mg/l (2016). Di tahun yang sama (1929) kandungan hara nitrogen sekitar 0,350-0,650 mg/l. Perubahan kedua hara tersebut telah diduga berasal dari KJA, limbah domestik dan peternakan yang masing-masing berkontribusi sebesar $66 \% \mathrm{~N}$ dan $50 \%$ P; $21 \% \mathrm{~N}$, dan $17 \% \mathrm{P}$; serta $7 \% \mathrm{~N}$ dan $3 \% \mathrm{P}^{(8)}$.

Penelitian tentang kualitas air danau khususnya yang terkait dengan tingkat kesuburan air telah banyak dipublikasikan. Berdasarkan data yang ada telah dapat diperoleh gambaran kondisi Danau Toba secara umum sebagaimana telah disampaikan diatas. Untuk hasil penelitian terkait dengan kandungan parameter logam berat masih sangat terbatas pada lokasi dan jenis logam tertentu ${ }^{(10,11)}$. Tampubolon dkk. ${ }^{(11)}$ telah mempublikasikan hasil penelitian kandungan logam berat dalam air Danau Toba pada tiga lokasi yaitu lokasi iinlet danau, lokasi KJA Karanggaol dan lokasi outlet danau. Hasil penelitian menunjukkan bahwa bahwa kandungan logam berat di lokasi inlet masing-masing adalah $\mathrm{Cu}(0,026-0,027 \mathrm{mg} / \mathrm{l})$ dan $\mathrm{Pb}(0,033-0,044 \mathrm{mg} / \mathrm{l})$; di lokasi outlet adalah $\mathrm{Cu}(0,020-0,045 \mathrm{mg} / \mathrm{l})$ dan $\mathrm{Pb}(0,029$ $0,030 \mathrm{mg} / \mathrm{l})$; sedangkan di lokasi KJA adalah $\mathrm{Cu}$ $\left(0,022-0,029 \mathrm{mg} / \mathrm{l}\right.$ dan $\mathrm{Pb}(0,013-0,014 \mathrm{mg} /)^{(11)}$. 
Melengkapi penelitian tentang kualitas kandungan logam berat di perairan Danau Toba yang telah disampaikan di atas, Garno dkk.(10) telah mempublikasikan hasil penelitian kualitas kandungan logam berat di perairan lokasi Kecamatan Ajibata Kabupaten Toba Samosir( ${ }^{(9)}$. Hasil penelitiaannya menunjukkan bahwa kandungan logam As (arsen), Co (cobalt), Ba (barium), B (boron), Se (selenium), Cd (cadmium), $\mathrm{Cr}^{6+}$ (chromium hexavalent), $\mathrm{Cu}^{*}$ (copper), $\mathrm{Pb}$ (lead), $\mathrm{Mn}$ (manganese), $\mathrm{Hg}^{*}$ (air raksa), $\mathrm{Zn}^{*}$ (seng), dan $\mathrm{F}^{-*}$ (florida) lebih rendah dari baku mutu yang berlaku untuk air Danau Toba saat itu, sedangkan kandungan kandungan $\mathrm{Fe}^{*}$ (besi) tercatat berkisar antara 0,841-1,036 $\mathrm{mg} / \mathrm{l}$ melebihi baku mutu yang berlaku untuk air baku air bersih $(0,3 \mathrm{mg} /)^{(4,9)}$.

Disamping penelitian tentang kualitas logam berat pada lokasi perairan yang sama Garno dkk. ${ }^{(10)}$ juga telah mempublikasikan hasil penelitian terhadap parameter lain, yaitu parameter klorida, BOD dan COD. Hasil penelitiannya menunjukkan bahwa kualitas $\mathrm{Cl}^{-}$ (klorida), BOD dan COD di perairan lokasi Kecamatan Ajibata Kabupaten Toba Samosir telah melebihi baku mutu yang berlaku saat itu yaitu Peraturan Gubernur Sumatera Utara Nomor 1 Tahun 2009 tentang Baku Mutu Air Danau Toba di Sumatera Utara ${ }^{(12)}$.

\subsection{Tujuan}

Tujuan penelitian ini adalah untuk mengetahui kelayakan kualitas air Danau Toba khususnya diperairan lokasi Kecamatan Ajibata Kabupaten Toba Samosir sebaga ar baku air minum dan sarana prasarana rekreasi air.

\section{BAHAN DAN METODE}

\subsection{Pengambilan sampel}

Kajian ini dilakukan pada Bulan September 2017. Pengambilan sampel dan pengukuran sifat fisik air di 4 (empat) lokasi di wilayah Kecamatan Muara Kabupaten Tapanuli Utara (Gambar 1). Kegiatan lapangan yang dilakukan meliputi pengamatan in-situ dan pengambilan sampel untuk analisis laboratorium. Pengamatan in-situ meliputi pengukuran temperatur air, kekeruhan dan $\mathrm{pH}$. Pengambilan sampel air dilakukan dengan menggunakan water kammerer sampler dan diawetkan, yang selanjutnya dianalisakan di laboratorium Global Quality Analitical Bogor. Pengambilan sampel air permukaan dilakukan sesuai prosedur ISO 56676:2014, sedangkan tata cara pengawetan dan penanganan sampel air mengikuti prosedur ISO 5667-3:2012.

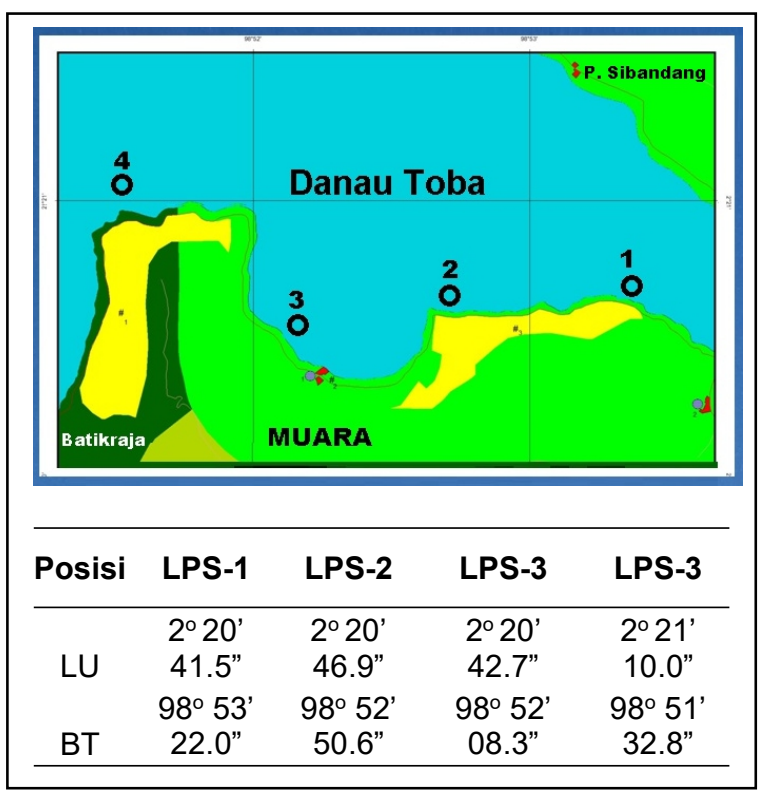

Gambar 1. Lokasi Pengambilan Sampel (LPS)

\subsection{Analisis sampel}

Metode yang digunakan untuk analisis sampel seperti disajikan pada Tabel 1.

\subsection{Analisis Data}

Nilai setiap parameter kualitas air Danau Toba hasil pengukuran di lokasi pengambilan sampel (LPS) 1-4 disajikan dalam bentuk tabel dengan 6 lajur. Lajur ke-1 sampai 4 berisi angka data parameter kualitas air dari 4 lokasi pengambilan sampel, sedangkan lajur ke- 5 dan 6 berturut-turut berisi angka parameter baku mutu air klas satu dan air klas dua berdasarkan Lampiran VI Peraturan Pemerintah Republik Indonesia Nomor 22 Tahun 2021 Tentang Penyelenggaraan Perlindungan dan Pengelolaan Lingkungan Hidup. Penyandingan baku mutu klas satu dilakukan untuk membahas kelayakan air danau sebagai air baku air minum, sedangkan penyandingan kelas dua dilakukan untuk membahas kelayakan air danau untuk sarana dan prasarana (sarpras) rekreasi air.

\section{HASIL DAN PEMBAHASAN.}

\subsection{Fisik dan kimia non logam}

Hasil analisis parameter fisik dan kimia pada air waduk Danau Toba Wilayah Kabupaten Tapanuli Utara secara lengkap disajikan pada Tabel 2. Dari tabel tersebut dapat diketahui bahwa air Danau Toba wilayah Kabupaten Tapanuli Utara di 4 (empat) lokasi pengambilan sampel (LPS) pada waktu kajian dilakukan memiliki temperatur air berkisar antara 25,9$26,7^{\circ} \mathrm{C}$. Untuk perairan tropis kisaran temperatur tersebut adalah nilai yang normal. Parameter fisik lain yang diukur adalah TDS dan LPSS. 
TDS berkisar antara 81-84 mg/l dan LPSS 3-5 $\mathrm{mg} / \mathrm{l}$. Kisaran nilai TDS dan LPSS tersebut adalah lebih kecil dari baku mutu air danau kelas satu dan kelas dua (Tabel 2). Hasil ini menunjukkan bahwa air di 4 (empat) lokasi pengambilan sampel masih layak untuk air baku air minum dan sarpras rekreasi air.

Tabel 1. Metode yang digunakan untuk analisis sampel

\begin{tabular}{|c|c|}
\hline Parameter & Metode \\
\hline \multicolumn{2}{|l|}{ Sifat Fisik } \\
\hline Temperature $\left({ }^{\circ} \mathrm{C}\right)$ & $5.4 / \mathrm{IK} / \mathrm{GQA} / \mathrm{WQ} / 002$ \\
\hline TDS (mg/l) & SNI 06-6989.27-2005 \\
\hline TSS (mg/l) & SNI 06-6989.3-2004 \\
\hline \multicolumn{2}{|l|}{ Sifat Kimia } \\
\hline$\overline{\mathrm{pH}}$ & SNI 06-6989.11-2004 \\
\hline $\mathrm{BOD}_{5}(\mathrm{mg} / \mathrm{l})$ & SNI 6989.72:2009 \\
\hline COD (mg/l) & SNI 6989.2:2009 \\
\hline Oksigen terlarut, DO• (mg/l) & SNI 06-6989.14-2004 \\
\hline Total pospat as $\mathrm{P}(\mathrm{mg} / \mathrm{l})$ & 5.4-IK-GQA-WQ-062 \\
\hline Nitrat-N ( $\left.\mathrm{NO}_{3}-\mathrm{N}\right)(\mathrm{mg} / \mathrm{l})$ & 5.4-IK-GQA-WQ-043 \\
\hline Nitrit- $\mathrm{N}\left(\mathrm{NO}_{2}-\mathrm{N}\right)(\mathrm{mg} / \mathrm{l})$ & SNI 06-6989.9-2004 \\
\hline Ammonia, $\mathrm{NH}_{3}-\mathrm{N}(\mathrm{mg} / \mathrm{l})$ & SNI 06-6989.30-2005 \\
\hline Hidrogen Sulfid, $\mathrm{H}_{2} \mathrm{~S}$ (mg/l) & SNI 6989.70:2009 \\
\hline Sulphate, $\mathrm{SO}_{4}{ }^{2-}(\mathrm{mg} / \mathrm{l})$ & SNI 6989.20:2009 \\
\hline Klorida, $\mathrm{Cl}^{-}(\mathrm{mg} / \mathrm{l})$ & SNI 6989.19:2009 \\
\hline Fluoride, $\mathrm{F}^{-}(\mathrm{mg} / \mathrm{l})$ & SNI 06-6989.29-2005 \\
\hline \multicolumn{2}{|l|}{ Logam } \\
\hline Besi, Fe (mg/l) & SNI 6989.4-2009 \\
\hline Seng, Zn (mg/l) & SNI 6989.7-2009 \\
\hline Mangan, Mn (mg/l) & SNI 6989.5-2009 \\
\hline Tembaga, Cu (mg/l) & SNI 6989.6:2009 \\
\hline Arsen, As (mg/l) & SNI 06-6989.54-2005 \\
\hline Cyanida, CN (mg/l) & 5.4-IK-GQA-WQ-058 \\
\hline Air raksa, $\mathrm{Hg}(\mathrm{mg} / \mathrm{l})$ & SNI 6989.78:2009 \\
\hline Cadmium, Cd (mg/l) & SNI 06-6989.38-2005 \\
\hline Timbal, $\mathrm{Pb}(\mathrm{mg} / \mathrm{l})$ & SNI 6989.46:2009 \\
\hline Barium, Ba (mg/l) & SNI 06-6989.39-2005 \\
\hline Cobalt, Co (mg/l) & SNI 6989.68:2009 \\
\hline Selenium, Se (mg/l) & US EPA $7741 \mathrm{~A}$ \\
\hline Boron, B (mg/l) & 5.4-IK-GQA-WQ-060 \\
\hline $\mathrm{Cr}^{6+}(\mathrm{mg} / \mathrm{l})$ & SNI 6989.71:2009 \\
\hline \multicolumn{2}{|l|}{ Organik } \\
\hline Oil and Grease $(\mu \mathrm{g} / \mathrm{l})$ & SNI 06-6989.10-2011 \\
\hline Surfactants, MBAS (mg/l) & SNI 06-6989.51-2005 \\
\hline \multicolumn{2}{|l|}{ Mikrobiologi } \\
\hline Total Coliform (MPN/100ml) & APHA $9221 \mathrm{~B}$ \\
\hline Fecal Coliform (MPN/100 ml) & APHA $9221 \mathrm{E}$ \\
\hline
\end{tabular}

Selain parameter fisik tersebut di atas, untuk memenuhi persyaratan sebagai baku air minum dan sarpras rekreasi air, kualitas air Danau Toba juga harus memenuhi persyaratan kualitas untuk parameter kimia non logam. Paremeter tersebut antara lain parameter derajat keasaman $(\mathrm{pH})$, BOD (Biological oxygen demand) dan COD (Chemical Oxygen Demand).

Hasil pengukuran in-situ menunjukkan bahwa pH air Danau Toba di 4 (empat) lokasi pengambilan sampel berkisar antara 7,71-8,01. Hal ini menunjukkan bahwa nilai hasil pengukuran $\mathrm{pH}$ lebih rendah dari kisaran baku mutu air danau yang ditentukan yaitu 6-9. Hasil ini menunjukkan bahwa kualitas air di empat lokasi layak untuk digunakan sebagai air baku air minum dan untuk keperluan rekreasi air.

Hasil pengukuran BOD sampel yang diambil dari lokasi pengambilan sampel 1,3 dan 4 berkisar antara 2,8-31,9 mg/l. Hasil ini jauh melebihi nilai baku mutu yang dipersyaratkan, yaitu $2 \mathrm{mg} / \mathrm{L}$ untuk persyaratan sebagai air baku air minum dan $3 \mathrm{mg} / \mathrm{L}$ untuk persyaratan sebagai sarpras rekreasi air.

Berbeda dengan ketiga lokasi pengambilan sampel ini, hasil pengukuran BOD di lokasi pengambilan sampel 2 menunjukkan nilai yang lebih kecil dari baku mutu yang dipersyaratkan, baik untuk persyaratan sebagai air baku air minum maupun untuk persyaratan sebagai sarpras rekreasi air. Dengan demikian maka air di ketiga lokasi pengambilan sampling (LPS-1, LPS-3 dan LPS-4), sudah tidak memenuhi persyaratan sebagai air baku air minum dan sarpras rekreasi air. Untuk air di LPS-2 meskipun tidak layak menjadi air baku air minum tetapi masih layak untuk sarpras tujuan rekreasi air.

Parameter lain yang dapat menentukan layak dan tidaknya air Danau Toba digunakan sebagai air baku air minum dan air untuk sapras adalah parameter COD. Parameter ini merupakan hasil pengukuran jumlah total oksigen didalam cairan sampel yang diperlukan untuk mengoksidasi bahan organik yang terlarut secara kimiawi, baik bahan organik yang dapat diurai (didegradasi) secara biologis maupun yang sukar diurai secara biologis. Hasil pengukuran COD air Danau Toba menunjukkan kisaran antara 22,23-88,57 mg/l. Hasil ini menunjukkan bahwa nilai COD air Danau Toba di keempat lokasi pengambilan sampel sudah melebihi baku mutu yang berlaku untuk air baku air minum $(10 \mathrm{mg} / \mathrm{l})$ sedangkan lokasi pengambilan sampel 1,2 dan 4 melebihi baku mutu untuk sarpras air $(25 \mathrm{mg} / \mathrm{l})$. Fenomena tersebut mengindikasikan bahwa air di empat lokasi pengambilan sampel tidak layak menjadi air baku air minum, dan hanya air di lokasi 3 yang layak untuk tujuan rekreasi air (Tabel 2). 
Tabel 2. Parameter fisik dan kimia pada air waduk Danau Toba Wilayah Kabupaten Tapanuli Utara

\begin{tabular}{|c|c|c|c|c|c|c|c|c|}
\hline \multirow{2}{*}{ No } & \multirow{2}{*}{ P A R A M E T ER } & \multirow{2}{*}{ Unit } & \multicolumn{4}{|c|}{ Lokasi Pengambilan Sampel } & \multicolumn{2}{|c|}{ BM } \\
\hline & & & 1 & 2 & 3 & 4 & Kelas-1 & Kelas-2 \\
\hline & Fisik & & & & & & & \\
\hline 1 & Suhu air & ${ }^{\circ} \mathrm{C}$ & 25.9 & 26.7 & 26 & 26.2 & Devi-3 & Devi-3 \\
\hline 2 & $\mathrm{BOD}_{5}$ & $\mathrm{mg} / \mathrm{l}$ & 84 & 83 & 81 & 84 & 1000 & 1000 \\
\hline \multirow[t]{2}{*}{3} & COD & $\mathrm{mg} / \mathrm{l}$ & 5 & 5 & 3 & 3 & 25 & 50 \\
\hline & Kimia & & & & & & & \\
\hline 1 & $\mathrm{pH}$ & - & 8,01 & 7,71 & 7,54 & 7,44 & $6-9$ & $6-9$ \\
\hline 2 & $\mathrm{BOD}_{5}$ & $\mathrm{mg} / \mathrm{l}$ & 6,1 & 31,9 & 2,8 & 11,1 & 2 & 3 \\
\hline 3 & COD & $\mathrm{mg} / \mathrm{l}$ & 48,70 & 25,48 & 22,23 & 88,57 & 10 & 25 \\
\hline 4 & Oksigen terlarut, DO• & $\mathrm{mg} / \mathrm{l}$ & 6,8 & 6,4 & 6,8 & 6,2 & 6 & 4 \\
\hline 5 & Total fosfat-P & $\mathrm{mg} / \mathrm{l}$ & 0,060 & 0,030 & 0,070 & 0,050 & 0,01 & 0,03 \\
\hline 6 & Total Nitrogen & $\mathrm{mg} / \mathrm{l}$ & 0,562 & 0,455 & 0,275 & 0,249 & 0,65 & 1,90 \\
\hline 7 & Hidrogen Sulfida, $\mathrm{H}_{2} \mathrm{~S}$ & $\mathrm{mg} / \mathrm{l}$ & - & $<0,0007$ & $<0,0007$ & $<0,0007$ & 0,002 & 0,002 \\
\hline 8 & Sulfate, $\mathrm{SO}_{4}^{2}$ & $\mathrm{mg} / \mathrm{l}$ & 12,48 & 3,06 & 1,47 & 1,19 & 300 & 300 \\
\hline 9 & klorida & $\mathrm{mg} / \mathrm{l}$ & 7,96 & 8,96 & 9,45 & 6,97 & 300 & 300 \\
\hline \multirow[t]{2}{*}{10} & Fluorida & $\mathrm{mg} / \mathrm{l}$ & $<0,024$ & 0,071 & 0,499 & 0,594 & 1,0 & 1,5 \\
\hline & Logam & & & & & & & \\
\hline 11 & Besi, Fe & $\mathrm{mg} / \mathrm{l}$ & 0,801 & 0,787 & 0,819 & 0,811 & 0,3 & \\
\hline 12 & Seng, Zn & $\mathrm{mg} / \mathrm{l}$ & 0,028 & 0,034 & 0,030 & 0,024 & 0,05 & 0,05 \\
\hline 13 & Mangan, Mn & $\mathrm{mg} / \mathrm{l}$ & $<0,007$ & $<0,007$ & $<0,007$ & $<0,007$ & 0,4 & 0,4 \\
\hline 14 & Tembaga, $\mathrm{Cu}$ & $\mathrm{mg} / \mathrm{l}$ & $<0,006$ & $<0,006$ & $<0,006$ & $<0,006$ & 0,02 & 0,02 \\
\hline 15 & Arsen, As & $\mathrm{mg} / \mathrm{l}$ & $<0,01$ & $<0,01$ & $<0,01$ & $<0,01$ & 0,05 & 0,05 \\
\hline 16 & Cyanida, CN & $\mathrm{mg} / \mathrm{l}$ & $<0,002$ & $<0,002$ & $<0,002$ & $<0,002$ & 0,02 & 0,02 \\
\hline 17 & Air Raksa, Hg & $\mathrm{mg} / \mathrm{l}$ & $<0,00009$ & $<0,00009$ & $<0,00009$ & $<0,00009$ & 0,001 & 0,002 \\
\hline 18 & Cadmium, Cd & $\mathrm{mg} / \mathrm{l}$ & 0,0001 & 0,00009 & 0,0002 & $<0,00004$ & 0,01 & 0,01 \\
\hline 19 & Timbal, Pb & $\mathrm{mg} / \mathrm{l}$ & 0,001 & 0,001 & 0,001 & 0,001 & 0,03 & 0,03 \\
\hline 20 & Barium, Ba & $\mathrm{mg} / \mathrm{l}$ & 2,598 & 3,003 & 3,171 & 2,305 & 1,0 & - \\
\hline 21 & Cobalt, Co & $\mathrm{mg} / \mathrm{l}$ & $<0,02$ & $<0,020$ & $<0,020$ & $<0,020$ & 0,2 & 0,2 \\
\hline 22 & Selenium, Se & $\mathrm{mg} / \mathrm{l}$ & $<0,006$ & $<0,006$ & $<0,006$ & $<0,006$ & 0,01 & 0,05 \\
\hline 23 & Boron, B & $\mathrm{mg} / \mathrm{l}$ & 0,3 & 0,4 & 1,1 & 1,0 & 1,0 & 1,0 \\
\hline \multirow[t]{2}{*}{24} & $\mathrm{Cr}^{6+}$ & $\mathrm{mg} / \mathrm{l}$ & 0,009 & 0,010 & $<0,001$ & $<0,001$ & 0,05 & 0,05 \\
\hline & Organik & & & & & & & \\
\hline 1 & Oil and Grease & $\mu g / l$ & $<1000$ & $<1000$ & $<1000$ & $<1000$ & 1 & 1 \\
\hline \multirow[t]{2}{*}{2} & Surfactants, MBAS & $\mathrm{mg} / \mathrm{l}$ & $<0,014$ & $<0,014$ & $<0,014$ & $<0,014$ & - & 0,2 \\
\hline & Mikrobiologi & & & & & & & \\
\hline 1 & Total Coliform & & 2 & $<2$ & 9 & 11 & 1.000 & 5.000 \\
\hline 2 & Fecal Coliform & $\mathrm{Jmi} / \mathrm{T} 00 \mathrm{mI}$ & $<2$ & $<2$ & 9 & 11 & 100 & 1.000 \\
\hline
\end{tabular}

Sumber : Data Primer, hasil sampling 22 September 2017

Keterangan: LPS = lokasi pengambilan sampel; BM = Baku mutu berdasarkan PP Nomor 22 Tahun 2021.

\begin{tabular}{|c|c|c|c|c|}
\hline Posisi & LPS-1 & LPS -2 & LPS-3 & LPS -3 \\
\hline LU & $2^{\circ} 20^{\prime} 41,5^{\prime \prime}$ & $2^{\circ} 20^{\prime} 46,9^{\prime \prime}$ & $2^{\circ} 20^{\prime} 42,7^{\prime \prime}$ & $2^{\circ} 21^{\prime} 10,0^{\prime \prime}$ \\
\hline BT & $98^{\circ} 53^{\prime} 22,0^{\prime \prime}$ & $98^{\circ} 52^{\prime} 50,6^{\prime \prime}$ & $98^{\circ} 52^{\prime} 08,3^{\prime \prime}$ & $98^{\circ} 51^{\prime} 32,8$ ' \\
\hline
\end{tabular}

Tingginya nilai parameter $\mathrm{BOD}$ dan $\mathrm{COD}$ dalam sampel air Danau Toba ini menunjukkan bahwa perairan Danau Toba, khususnya perairan di wilayah Kabupaten Tapanuli Utara telah tercemar berat oleh bahan-bahan organik yang tinggi yang menyebabkan terjadinya penurunan kualitas airnya. Pencemaran bahanbahan organik ini diduga kuat berasal dari aktifitas kegiatan perikanan yang menggunakan keramba jaring apung, baik bahan organik yang berupa sisa pakan ikan maupun dari kotoran ikan ${ }^{(13,14)}$. Tingginya nilai BOD dan COD yang telah melebihi nilai baku mutu air untuk baku air minum, maupun baku untuk tujuan rekreasi air di perairan Danau Toba, khususnya air perairan di wilayah Kabupaten Toba Samosir, juga telah dilaporkan oleh Garno dkk. ${ }^{(10)}$ 
Pencemaran bahan-bahan organik dalam suatu badan air direpresentasikan dengan naiknya nilai BOD dan COD, dan penurunan konsentrasi oksigen terlarut (DO) dalam badan air. Penurunan konsentrasi oksigen terlarut ini disebabkan karena oksigen terlarut yang ada digunakan untuk mendekomposisi bahan pencemar organik dalam badan air sehingga jumlahnya berkurang(15). Hasil pengukuran nilai DO pada penelitian ini diperoleh nilai kisaran konsentrasi antara 6,2-6,8 mg/l. Nilai konsentrasi DO ini masih memenuhi baku mutu yang berlaku, yakni minimum $6 \mathrm{mg} / \mathrm{l}$.

Secara teoritis dengan hasil pengukuran insitu terhadap temperatur badan air dengan nilai kisaran antara $25,9-26,7^{\circ} \mathrm{C}$ maka seharusnya nilai DO di lokasi sampling tersebut dapat mendekati konsentrasi maksimal (jenuh) yaitu pada kisaran 7,90-8,00 mg/(16). Namun hasil pengukuran riil diperoleh nilai DO pada kisaran nilai antara 6,2-6,8 mg/l. Ketidakmampuan mencapai/mendekati konsentrasi jenuh tersebut diduga karena oksigen hasil fotosintesa dan difusi udara ke dalam badan air digunakan oleh bakteri untuk mendegradasi organik pencemar yang menghasilkan fosfor-inorganik, nitrogen inorganik, $\mathrm{H}_{2} \mathrm{~S}$ dan gas lainnya.

Dari Tabel 2 dapat diketahui bahwa konsentrasi total fosfat dalam badan air berkisar antara 0,030-0,070 mg/l. Dibandingkan dengan baku mutu air danau untuk air baku air minum $(0,01 \mathrm{mg} / \mathrm{l})$ dan baku mutu untuk sarpras rekreasi air $(0,03 \mathrm{mg} / \mathrm{l})$ mengindikasikan bahwa air Danau Toba di wilayah Kabupaten Tapanuli Utara sudah tidak layak sebagai air baku air minum dan sarpras rekreasi.

Berbeda dengan total fosfat, berdasarkan total nitrogen yang 0,249-0,562 $\mathrm{mg} / \mathrm{l}$ maka air Danau Toba wilayah Kabupaten Tapanuli Utara masih layak untuk air baku air minum dan sarpras rekreasi air. Hal ini karena baku mutu yang berlaku pada air Danau Toba adalah 0,065 $\mathrm{mg} / \mathrm{l}$ untuk air baku air minum dan 1,90 mg/l untuk sarpras rekreasi atau lebih tinggi dari konsentasi yang ditemukan.

Berdasarkan pembahasan di atas, secara umum konsentrasi total fosfor dan nitrogen yang tinggi dalam perairan tidak dikehendaki. Hal ini disebabkan karena konsetrasi fosfor dan nitrogen yang tinggi akan merangsang pertumbuhan fitoplankton dengan pesat yang akhirnya dapat menyebabkan terjadinya algal bloom $^{(17)}$

Dekomposisi juga melepaskan $\mathrm{H}_{2} \mathrm{~S}$ yang jika mengalami oksidasi berlanjut menjadi $\mathrm{H}_{2} \mathrm{SO}_{4}$. Tabel 2 menunjukkan bahwa pada konsentrasi lebih kecil dari 0,0007 mg S/L sulfida akan lebih stabil, sedangkan untuk sulfat stabilitasnya berfluktuasi pada kisaran antara 1,19-12,48 mg $\mathrm{SO}_{4} / \mathrm{l}$. Bila dibandingkan dengan baku mutu yang berlaku, baik konsentrasi sulfida maupun konsentrasi sulfat tersebut jauh lebih kecil sehingga dapat dinyatakan bahwa air Danau Toba layak untuk air baku air minum maupun untuk sarpras rekreasi air.

Parameter non logam lain yang keberadaannya sangat mempengruhi kualitas air danau adalah klorida dan florida. Hasil pengukuran konsentrasi kedua parameter sebagaimana disajikan dalam Tabel 2 diketahui masih lebih rendah dibanding baku mutu yang berlaku. Konsentrasi parameter klorida terukur antara 6,97-9,45 mg/l, sehingga konsentrasi ini lebih rendah dibandingkan dengan baku mutu untuk air baku air minum dan sarpras rekreasi (300 mg/l). Demikian pula dengan parameter florida yang terukur antara 0,024-0,594 mg/l lebih kecil dibandingkan dengan baku mutu untuk air baku air minum (1,0 mg/l) dan baku mutu untuk sarpras rekreasi air (1,5 mg/l). Dengan demikian maka berdasarkan konsentrasi klorida dan florida tersebut dapat dinyatakan bahwa air Danau Toba di wilayah Tapanuli Utara layak untuk air baku air minum dan sarpras rekreasi air.

\subsection{Logam}

Kandungan logam, terutama logam berat dalam air danau merupakan parameter yang mempengaruhi layak dan tidaknya air danau untuk digunakan sebagai air baku air minum maupun sebagai sarana rekreasi air. Secara alami, logam-logam ini telah terkandung di dalam air danau dengan konsentrasi yang rendah. Keberadaan logam ini secara alami dalam bentuk senyawa sulfida maupun dalam bentuk mineral yang tersusun unsur-unsur kimia logam, oksigen, silika dan sulfur. Konsentrasi kandungan logam di air perairan danau yang secara alami masih sangat rendah ini dapat meningkat karena adanya kegiatan penambangan, seperti kadmium (Cd) yang ditemukan pada proses pencairan seng(18).

Dalam jumlah yang kecil, beberapa logam sangat diperlukan untuk memenuhi kebutuhan kehidupan sebagai elemen mikro. Logam-logam tersebut antara lain $\mathrm{Fe}, \mathrm{Zn}, \mathrm{Mn}$ dan $\mathrm{Cu}$. Disisi lain keberadaan logam berat seperti $\mathrm{As}, \mathrm{CN}, \mathrm{Hg}$, $\mathrm{Cd}, \mathrm{Pb}, \mathrm{Cu}, \mathrm{Co}, \mathrm{Cr}$ dan $\mathrm{Se}$ ini sangat membahayakan kehidupan karena dapat bersifat racun terhadap manusia, binatang dan tanaman, meskipun belum diketahui perannya dalam proses metabolisme ${ }^{(19)}$. Berdasarkan hal ini maka pengukuran konsentrasi logam, khususnya logam berat dalam air yang akan digunakan untuk kegiatan manusia secara langsung perlu diketahui sejak awal, seperti sebagai bahan baku air minum dan sarpras rekreasi air. Untuk kedua kegiatan ini perlu diketahui dan dipastikan konsentrasi logam-logam berat lebih kecil dari 
baku mutu yang berlaku agar tidak membahayakan dalam pemanfaatannya.

Pada saat penelitian dilaksanakan kandungan logam dalam perairan Danau Toba di 4 (empat) lokasi pengambilan sampel di wilayah Tapanuli Utara sebagaimana disajikan dalam Tabel 2, menunjukkan bahwa nilai konsentrasi masing-masing parameter logam berat, kecuali $\mathrm{Fe}$ dan $\mathrm{Ba}$, masih berada dibawah nilai baku mutu masing-masing peruntukan, baik sebagai baku mutu untuk air baku air minum maupun untuk sarpras rekreasi air.

Kandungan logam $\mathrm{Fe}$ dan Ba dari 4 (empat) lokasi pengambilan sampel masing-masing berkisar antara 0,7870-0,819 mg/l dan 2,598$3,171 \mathrm{mg} / \mathrm{l}$, telah melebihi nilai ambang batas baku air danau untuk bahan baku air minum, yaitu 0,3 mg/l (Fe) dan 1,0 mg/l (Ba), sedangkan untuk keperluan sarpras rekreasi, baku mutu untuk $\mathrm{Fe}$ dan $\mathrm{Ba}$ tidak dipersyaratkan nilai maksimumnya. Berdasarkan data hasil penelitian ini dapat dinyatakan bahwa berdasarkan kandungan $\mathrm{Fe}$ dan $\mathrm{Ba}$, air Danau Toba di 4 (empat) lokasi pengambilan sampel diwilayah Kabupaten Tapanuli Utara tidak layak diperuntukan bagi keperluan air baku air minum, tetapi untuk keperluan sarpras rekreasi masih diperbolehkan.

Fenomena tingginya konsentrasi besi $\mathrm{Fe}$ juga terjadi di wilayah Kabupaten Toba Samosir(10), dimana nilai parameter besi lebih tinggi dari baku mutu yang berlaku saat itu(12). Dalam air minum, konsentrasi Fe yang tinggi tidak dikehendaki karena akan berdampak terhadap kesehatan diantaranya bisa menyebabkan keracunan (muntah) dan kerusakan usus(20), sedangkan senyawa barium yang larut dalam air beracun dalam dosis rendah, ion barium bertindak sebagai stimulan otot, dan dosis yang lebih tinggi dapat mempengaruhi sistem saraf, dan menyebabkan penyimpangan jantung, tremor, kelemahan, kegelisahan, sesak napas, dan kelumpuhan ${ }^{(21)}$.

\subsection{Mikrobiologi}

Kandungan komponen mikrobiologi, seperti bakteri coli menjadi salah satu persyaratan diperbolehkannya atau tidak diperbolehkannya air danau dimanfaatkan sebagai air baku untuk air minum maupun pemanfaatan perairannya sebagai sarpras rekreasi air. Bakteri coli yang dalam Bahasa latin disebut Escherichia coli ( $E$. coli) adalah bakteri yang hidup di dalam usus manusia yang berfungsi untuk menjaga kesehatan sistem pencernaan, dan pada umumnya tidak membahayakan kesehatan manusia(22). Meskipun demikian, untuk jenis tertentu dari bakteri ini dapat membahayakan kesehatan manusia karena kemampuannya menghasilkan racun yang dapat menyebabkan diare pada manusia. Bakteri E. coli yang berbahaya ini dapat masuk ke dalam tubuh manusia melalui makanan dan minuman yang telah terkontaminasi bakteri E. coli; serta melalui kontak langsung dengan bakteri tersebut.

Nilai kandungan parameter mikroba di dalam air diukur sebagai nilai total coliform dan coliform Fecal. Total coliform adalah suatu kelompok bakteri yang digunakan sebagai indikator adanya polusi kotoran. Total coliform yang berada di dalam makanan atau minuman menunjukkan kemungkinan adanya mikroba yang bersifat enteropatogenik dan atau toksigenik yang berbahaya bagi kesehatan. Total coliform dibagi menjadi dua golongan, yaitu coliform fecal, seperti $E$. coli yang berasal dari tinja manusia, hewan berdarah panas, dan coliform nonfecal, seperti Aerobacter dan Klebsiella yang bukan berasal dari tinja manusia, tetapi berasal dari hewan atau tanaman yang telah mati. Nilai total coliform dan fecal coliform untuk baku mutu air baku air minum masing-masing adalah 1.000 ind/100 ml dan 100 ind/100 ml, sedangkan nilai total coliform dan fecal coliform untuk baku mutu sarpras masing-masing adalah 5.000 ind/100 ml dan $1.000 \mathrm{ind} / 100 \mathrm{ml}$.

Penelitian ini mengungkapkan bahwa kandungan total coliform dan coliform fecal dalam air Danau Toba masing-masing adalah 2$11 \mathrm{ind} / 100 \mathrm{ml}$ dan 2-11 ind/100 ml. Kandungan parameter mikroba ini masih jauh lebih kecil dibandingkan dengan nilai baku mutu yang ditetapkan. Dibandingkan dengan hasil penelitian para peneliti sebelumnya, jumlah total coliform di wilayah Kabupaten Tapanuli Utara ini lebih kecil dari total coliform di perairan Pantai Sibolazi Desa Simanindo Kabupaten Samosir $(150-770 \text { ind/100 ml })^{(23)}$ dan juga jauh lebih kecil dari perairan Danau Toba di sekitar KJA di Desa Lumban Binanga, Kecamatan Laguboti, Kabupaten Toba Samosir (2800 MPN/100 ml $16000 \mathrm{MPN} / 100 \mathrm{ml})^{(24)}$. Berdasarkan hasil penelitian ini, dapat dinyatakan bahwa kandungan total coliform dan E. coli dalam air Danau Toba di wilayah Kabupaten Tapanuli Utara masih rendah dan layak digunakan untuk air baku air minum maupun sebagai sarana dan prasarana rekreasi.

\section{KESIMPULAN}

Berdasarkan pembahasan tersebut di atas dapat disimpulkan bahwa air Danau Toba di wilayah Kabupaten Tapanuli Utara mengandung parameter BOD, COD, total fosfat, Besi, dan Barium yang melebihi nilai baku mutu untuk air baku air minum dan sarana prasarana rekreasi air yang berlaku sehingga secara umum dapat dikatakan belum layak untuk menjadi air baku air minum dan sarpras rekreasi. Untuk memanfaatkan air Danau Toba di wilayah 
Kabupaten Tapanuli Utara tersebut diperlukan upaya penurunan parameter-parameter tersebut agar memenuhi baku mutu yang sesuai dengan Peraturan Pemerintah Republik Indonesia Nomor 22 Tahun 2021 tentang Penyelenggaraan Perlindungan dan Pengelolaan Lingkungan Hidup.

\section{PERSANTUNAN}

Penulis mengucapkan banyak terima kasih Kepada Direktur Pusat Teknologi Lingkungan BPPT yang telah memberikan ijin untuk melaksanakan penelitian ini. Juga tidak lupa diucapkan terima kasih kepada Direktur Destinasi Wisata Badan Pelaksana Otorita Danau Toba atas kerjasamanya sehingga penelitian ini dapat dilaksanakan dengan lancar tanpa hambatan yang berarti.

\section{DAFTAR PUSTAKA}

1. Lukman \& Ridwansyah. (2010). Kajian Kondisi Morfometri dan Beberapa Parameter Stratifikasi Perairan Danau Toba. Limnotek 17 (2).

2. Eyanoer F., Sebiring M., Medju Sj. Damanik \& Anwar. (1980). Laporan Akhir Komunitas Lingkungan Perairan dan Kehidupan Biologi Danau Toba Sumatera.

3. Anonim. (2011). Peraturan Pemerintah (PP) Nomor 50 Tahun 2011 tentang Rencana Induk Kepariwisataan Nasional Tahun 2010-2025.

4. Anonim. (2021). Peraturan Pemerintah Republik Indonesia Nomor 22 tahun 2021 tentang Penyelenggaraan Perlindungan dan Pengelolaan Lingkungan Hidup.

5. Lukman \& Hamdani, A. (2011). Estimasi Daya Dukung Perairan Danau Toba Sumatera Keramba Jaring Apung. Limnotek. 18(2), 5967.

6. Siagian, M.T. (2013). Model Pengelolaan Keramba Jaring Apung (KJA) Masyarakat Berkelanjutan di Danau Toba, (Disertasi), Sekolah Pascasarjana Universitas Sumatera Utara Medan.

7. Haro, D. D. (2013). Dampak Kegiatan Budidaya Keramba Jaring Apung Terhadap Kualitas Air Danau Toba di Kecamatan Haranggaol Horison Kabupaten Simalungun Sumatera Utara, (Skripsi), Program Studi Manajemen Sumberdaya Perairan Fakultas Pertanian Universitas Sumatera Utara.

8. Ruttner, F. (1930). Hydrographische und hydrochemishe Beobachtungen auf Java, Sumatera und Bali. Pp: 196-454. In: A. Thienemann.Archiv furhydrobiology.Organ Der Internationalen Fur Theoretische und
Angewandte Limnologie. Supplement-Band VIII. ESchweizerbart's che Verlagsbuchhandlung (Ewin Nagele) G.m.b.H.Stuttgart Poernomo, K., E. S.

9. Handayani, T., Suwedi, N., Darmawan, A., Riyadi, A., Aviantara, D. B., Sopiah, R. N., Suciati, F. (2016). Kualitas Air Danau Toba, Laporan Survey Kerjasama Menkomar dan BPPT.

10. Garno, Y. S., Nugroho R. \& Hanief, M. (2020). Kualitas air Danau Toba di wilayah Kabupaten Toba Samosir dan kelayakan peruntukannya, Jurnal Teknologi Lingkungan, 21 (1),118-124.

11. Tampubolon, H.S., Bakti, D., \& Lesmana,I. (2013). Studi Kandungan Logam Berat Tembaga $(\mathrm{Cu})$ dan Timbal $(\mathrm{Pb})$ di Perairan Danau Toba, Provinsi Sumatera Utara, Universitas Sumatera Utara.

12. Anonim, (2009). Peraturan Gubernur Sumatera Utara Nomor 1 Tahun 2009 tentang Baku Mutu Air Danau Toba di Sumatera Utara.

13. Gultom J. \& Panjaitan, P. (2009). Seminar Nasional Studi dampak Pencemaran pada Lokasi KJA PT. Aquafarm Nusantara. Tuktuk Kabupaten Samosir, Januari.

14.Rismawati R. (2010). Analisis Daya Dukung Perairan Danau Toba Terhadap Kegiatan Perikanan Sebagai Dasar Dalam Pengendalian Pencemaran Keramba Jaring Apung, (Tesis), Sekolah Pascasarjana Universitas Sumatera Utara Medan.

15. Garno, Y.S. (2002). Beban Pencemaran Limbah Perikanan Budidaya dan Yutrofikasi di Perairan Waduk pada DAS Citarum. Jurnal Teknologi Lingkungan, 3(2), 112-120.

16. Cole, G. A. (1988). Textbook of Limnology. Third edition. Waveland Press, Inc., Illionis, USA. 401 p. (11).

17. Hendersen B. \& Markland H.R. (1987). Decaying Lakes-The Origins and Control of Cultural Eutrofication. John \& Willey Sons Ltd. New York Chichester, Brisbane, Toronto, Singapura. Theor. Angew. Limnol. Verh., 20, 68-74.

18.EPA, "Water Quality Criteria," (1972) Ecological Res. Series, Washinton, 595 pp.

19. Mursidi, A. (2015). Analisis Risiko Kandungan Logam Kromium Heksavalen (Cr6+) Dan Arsen (As) Dalam Air Minum, Jurnal Vokasi Kesehatan, 1 (6), 195-204.

20. Parulian, A. (2009). Monitoring dan Analisis Kadar Aluminium (Al) dan Besi (Fe) pada Pengolahan Air Minum PDAM Tirtanadi 
Sunggal. Medan, (Tesis), Pascasarjana Universitas Sumatera Utara.

21. Anonim, (2021). https://id.wikipedia.org/ wiki/Barium

22.Denis, R. (2014). Identifikasi Bakteri Escherichia coli (E.coli) pada Air Galon Reverse Osmosis (RO) dan Non Reverse Osmosis (Non RO). Jurnal Gradien, 10(1), 967-971.

23. Tumanggor G.D. (2017). Studi Kualitas Air Danau Toba di Pantai Sibolazi Desa
Simanindo Kabupaten Samosir, Provinsi Sumatera Utara. Manajemen Sumberdaya Perairan, (Skripsi), Fakultas Pertanian. Universitas Sumatra Utara

24. Pangaribuan, O.P. (2020). Kualitas Air Dan Keluhan Kesehatan Pengguna Air Danau Toba Di Sekitar Keramba Jaringapung Lumban Binanga Laguboti. Program Studi S1 Kesehatan Masyarakat, (Skripsi), Fakultas Kesehatan Masyarakat Universitas Sumatera Utara 